Journal of Social Sciences 3 (2): 88-93, 2007

ISSN 1549-3652

(C) 2007 Science Publications

\title{
From Flexicurity to FlexicArity? Gendered Perspectives on the Danish model
}

\author{
Lise Lotte Hansen \\ Department of Society and Globalisation, Roskilde University, Denmark
}

\begin{abstract}
In Europe, flexicurity is seen as a way to develop labour markets so they will stay or be more competitive and at the same time secure the European welfare tradition. The Danish welfare society builds on a division of work and co-operation between the labour market and the welfare state. This division and co-operation also applies to the Danish flexicurity model which this article focuses on from a gender perspective. The analysis presented here relates to the labor market, the welfare state, and the active labor market policy. The article shows that welfare policies on public care and individual rights have supported women's labor market participation and economic and political empowerment. It is thus suggested to change the name to the Danish flexicarity model. Furthermore, the article shows that the active labor market policy does not improve women's employability to the same extent as men's and it is therefore suggested that further research into the gendered consequences of the active labor market policy should be undertaken.
\end{abstract}

Keywords: Labour market, welfare state, industrial relations, gender equality

\section{INTRODUCTION}

In the European Union, flexicurity is seen as a way to develop labour markets so they will stay or become more competitive and at the same time secure the European welfare tradition. The Danish flexicurity model is referred to as a specific successful example of flexicurity in praxis. The model consists of three parts: a flexible labour market, social security, and an active labour market policy. The success is in particular based on the combination of strong independent institutions at the labour market and their ability to make agreements on e.g. flexibility and an active labour market policy which focuses on developing the qualifications of the individual.

In Denmark, women are on the labour market in almost the same numbers as men (women 73,1\%, men 79,4 $\%)$; more than half of the women work fulltime or more, the average working time for women being 32.5 hours and for men 38.5 hours a week; until recently most of the collective agreements prohibited part-time jobs below 15 hours a week; there is no special protection of female labour; $49 \%$ of the union members in the LO (The Danish Confederation of Trade Unions) are women; as a group, women are almost as well educated as men; and in relation to being accepted for social benefits, all citizens have the obligation to provide for themselves first and foremost $[3,12,20]$.

Despite these facts and despite legislation on equal pay, the pay gap between men and women seems very persistent. The gender pay gap is between $13-19 \%$ with differences among sectors. If differences in education, job functions, and work experience between men and women are taken away the pay gap is $2-6 \%$. When taking a closer look a highly gender segregated vertical as well as horizontal - labor market is revealed: $60 \%$ of the workforce work in almost one-sex jobs, sections and branches. Men are in the majority in the private sector, in crafts, IT and in job functions which focus on development, as in leadership and management. Women are the majority in the public sector, in care and office work, and in ordinary jobs. Thus women are underrepresented in management both in private and public sectors. This is also the case in parliament, government, local government and in the labor movement $[3,8,20,21,26,30]$.

Women as a group are more often unemployed and for longer periods of time than men. On top of that, women also suffer from sickness to a higher degree than men, more women than men take early retirement, and they live longer [3]. Living longer than men and saving up less money - because of lower pay and more breaks from paid labour - negatively affects the size of women's labour market pensions.

On the one hand, the Danish flexicurity model is seen as successful, on the other gender inequality is widespread at the labour market and in the policy institutions that regulate the labour market. The objective of the article is to shed light on the relations between the flexicurity model and gender equality and inequality in the Danish welfare society.

\section{METHODOLOGIES}

The analytical perspective and the development of arguments are based on research in gender in the industrial relations tradition and in welfare state theories. The research points at gender-blindness in model-building, theories, methods, and analysis in traditional research. In the article focus is on modelbuilding and analysis [16].

Methodologically, the article is based on a desk study of data from the National Statistic Office, the National Institute for Social Research, the Ministry of Employment, the office of the Minister of Gender Equality, the LO (The Danish Confederation of Trade Unions), the DA (the Confederation of Danish Employers), and the union 3F. This is supplemented by 
research about fair representation and gender equality in the Danish union 3F conducted by Lise Lotte Hansen and Steen Scheuer during 2006.

\section{RESULTS}

Flexicurity: Flexicurity is a contraction of flexibility and security. This flexibility-security nexus - as Ton Wilthagen and Frank Tros call it - has been the concern of workers, companies, the labour movement, the employers' organisations and national politicians, and it has been on the European Union agenda for more than 10 years. The concern is to meet the demands both to make labour markets, employment and work organisations more flexible and to provide security to employees, especially the vulnerable groups [32].

The literature offers different versions of what flexicurity is: A strategy, a model, or an analytical framework? [18, 32]. According to the often quoted definition by Wilthagen \& Tros flexicurity is:

'A policy strategy that attempts synchronically and in a deliberate way, to enhance the flexibility of labour markets, work organisation and labour relations on the one hand, and to enhance security - employment security and social security - notably for weaker groups in and outside the labour market, on the other hand' [32:169].

Flexibility and security take different forms in different national contexts. For example flexibility covers numerical flexibility, functional flexibility and working time flexibility while security can mean both job security and social security.

The Danish flexicurity model: The Danish welfare society builds on a division of work and co-operation between the labour market and the labour market parties on the one hand, and the welfare state on the other. The Danish flexicurity model is also a result of this division of work and co-operation. It combines labour market flexibility (building on collective and local agreements between the unions and the employer's organisations) and social security (state benefits and unemployment insurance funds partly controlled by unions) with an active labour market policy.

The Danish flexicurity model consists of:

' - A flexible labour market with a high level of external numerical flexibility indicated by high level of worker flows in and out of employment and unemployment; the high degree of numerical flexibility is made possible by a low level of employment protection, allowing employers to freely adapt the workforce to changing economic conditions

- A generous system of economic support for the unemployed

- Active labour market policies aimed at upgrading the skills of those unemployed, that are unable to return directly from unemployment to a new job'. [23:269]

The Danish flexicurity model is a 'golden triangle' that as its core relation and mutual interaction has in one corner a high level of numerical flexibility with a low level of employment protection and in the other economic security provided mainly by the welfare state. The third corner of the triangle is the active labour market policy $[22,23,24]$. The active labour market policy is financed by the welfare state and it supports both the flexibility of the labour market and the security dimension by up-grading the skills and qualifications among the unemployed.

The active labour market policy and the tradition for making agreements between the labour market parties about not only pay, but a wide range of issues for instance flexibility are particularly important.

According to Madsen, the Danish flexicurity model distinguishes itself by being able to provide a flexible labour market which is comparable to liberal labour markets (e.g. UK and USA) while it at the same time provides a safety net which is comparable to the other Scandinavian welfare states [24]. Thus the Danish flexicurity model both meets the 'demands' of the globalized labour market and protects the citizens: the Danish flexicurity model dissolves the opposition between flexibility and security [25]. Despite arguing for the Danish flexicurity model as the way forward for the EU-labour market and emphasize Denmark as the 'great pretender' building on the strength of the Danish economy [25], Madsen also identifies some problems e.g. the expelling of larger groups because of low productivity and challenges e.g. from the growing group of immigrants [24].

In the following I will add gender to the three dimensions in the flexicurity model.

The Danish labour market model: The Danish labour market model, like to a high degree the other Nordic countries, is a combination of two different industrial relations regimes: neo-corporation and pluralism [10, 27]. The Danish labour market model is characterised by two features. Firstly, the labour market parties (employee's and employer's organisations) have a great deal of influence, and secondly, most issues that have traditionally been related to the labour market are regulated through collective bargaining for instance work-time flexibility. This is still the case, but multilevel regulation is getting stronger in the Danish model due both to EU-legal regulation concerning labour market issues and to a commencing use of the erga omnes principle (i.e. it shall cover all employees) as in the case of the Parental Leave Fund [10,27]. However, some areas have also been regulated by law either fully, or as a supplement to the collective agreements e.g. regulations on health and safety, holiday and maternity leave. Pay is generally seen as one of the areas which have been fully regulated by the labour market parties, but this is only true if the law on equal pay is not taken into consideration. In 1973, equal pay for equal work became part of the collective agreements after a long period of pressure from women members of the LO. In 1976, equal pay was made into a law which was changed in 1986 as a consequence of EU ruling. The legal text now states that there should be equal pay for equal work and work of equal value 
[31]. The bargaining system has changed from one mainly building on collective bargaining to one based on multilevel bargaining i.e. the collective agreement fixes the minimum pay which is followed up by bargaining at the local level. In the public sector, 'New Pay' has also meant a decentralisation of pay bargaining, though to a lesser degree than in the private sector. In both the private and the public sectors, the decentralisation of bargaining has meant an increase in pay differentials. However, some groups of women have also gained from the new system for instance nurses [7, 27].

The labour market has strong, independent, institutions developed and controlled by the parties. However, there is also a strong tradition for negotiations and policymaking including the state (and local governments) both concerning labour market policy and broader welfare problems. This takes place, for instance, in committees, councils and boards (tripartism). The emphasis is on social partnership and on reaching consensus when possible while building on the respect of difference in interests at the same time $[9,10]$.

In comparison to most other European countries, the labour movement and the independent industrial relations system maintain a powerful position in Danish society. The labour market is well organised both on the employer's and the employee's sides. Most employees are union members: $76.8 \%$ in 2005 equally divided between men and women, manual workers and salaried employees, furthermore the coverage by agreements is almost total in the public sector and $71 \%$ in the private sector [27]. Danish unions organise mostly in relation to trade and education and there are three confederations: the LO (The Danish Confederation of Trade Unions), FTF (The Confederation of Unions for Salaried Employees and Civil Servants), and AC (the Danish Confederation of Professional Associations). Despite making up half of the membership women is still strongly underrepresented in leadership positions in the labour movement. The LO gender equality score for 2005 shows only minor changes in female representation in comparison to previous years. On average women make up $43 \%$ of the shop stewards, $31 \%$ at congresses, $24 \%$ in central boards, and $22 \%$ of the executive committees. There are no female chairmen in the LO and the bargaining cartels, but $40 \%$ of vice-chairmen, $6 \%$ of central union chairmen, $25 \%$ of vice-chairmen, and $20 \%$ of local chairmen are women. These numbers cover up both decline and progress distributed at different levels and unions. On the whole, the numbers show a minor decline since 2004 [21].

The Danish welfare state mode: The Danish welfare state model belongs to the social-democratic welfare regime together with the other Nordic countries [12, 14, 19]. Three fundamental values characterise the welfare state model: universalism, equality and solidarity. Universalism is the principle used both in regard to social security and to social services and every citizen has the right to social security when affected by a specific event and independent of family relations. This principle of individualism has supported women's economic independence and labour market participation. Social security is financed by taxes while some social services are free e.g. home-help and others are partly paid by the users e.g. children's day-care. The Danish welfare society is a dual-breadwinner and substitute carer regime $[4,18]$. That is, that the welfare state takes over parts of the care work from the doubleearner family. The Danish welfare state is characterised by relatively good and cheap public care facilities for children, the sick, and the elderly, and free education from primary school to university. The public care facilities have supported women's labour market participation and the reconciling of family and work. The progressive tax-system is the main area where solidarity can be found in the welfare model and it is closely connected to the principle of equality which mainly means economic and social equality. On the one hand, neither particularistic nor recognition policies are part of the welfare strategies, and the Danish welfare state model has been criticized for building on a hidden norm of homogeneity [6]. On the other, the principle of equality has been used as a platform to fight for women's rights, and equal opportunities legislation and gender equality policies are established parts of the Danish welfare society $[2,4,11,28]$. However, women have not yet obtained equal political representation (Table 1).

The active labour market policy: Women are more affected by unemployment than men, so they are also more dependent on the active labour market policy to provide them with the right training and qualifications (Table 2). Generally, the effect of the active labour market policy on women's employability is lower than on men's. The 'scaring/motivation-effect' is lower in regard to women - while all types of activation programmes reduce the length of unemployment for men, the opposite is the case for women. In general women stay in active labour market programmes longer than men [3]. Women tend to take part in educationprogrammes (little more than $50 \%$ ) rather than wagesubsidy jobs where one finds a surplus of men (37\% of the women, $46 \%$ of the men). However, private wagesubsidy jobs are the best way to re-enter the labour market quickly and since 2002 the government has cut down on subsidies to education. Obviously, this has affected women the most. Research has shown that in the longer run education is just as effective a means to re-enter the labour market especially for women [15]. Finally, men get better wage conditions after taking part in activation programmes than women, men namely obtain a higher hourly wage and experience less fall in wages than women. However, in the longer run the probability for getting into work after activation is the same for women and men [13].

During 2006 there was a rise in blue-colour jobs in the private sector, but those mostly benefited men. Numbers from the biggest union for manual workers the 3F's unemployment insurance fund confirm this, male unemployment has fallen to $5 \%$ while the female unemployment still is $10 \%$. As a local 
Table 1: Women, men and political representation, 2005 and 2007

\begin{tabular}{lllll}
\hline & Parliament & Government & Municipal council & Mayor \\
Women & $37 \%$ & $26 \%$ & $27 \%$ & $7 \%$ \\
Men & $62 \%$ & $74 \%$ & $73 \%$ & $93 \%$ \\
\hline
\end{tabular}

Source: Minister for ligestilling

Table 2: Unemployment and activation, men and women

\begin{tabular}{llll}
\hline & Unemployed & Long-term unemployed & Activated by AF \\
Women & $5,3 \%$ & $58,9 \%$ & $64 \%$ \\
Men & $3,7 \%$ & $40,1 \%$ & $36 \%$ \\
\hline
\end{tabular}

Source: Beskæftigelsesministeriet 2006

leader of the unemployment insurance fund said, 'They are all in jobs now, except for the women of the wrong age (past 50) and the wrong name (ethnic minorities)'. In some of the local $3 \mathrm{~F}$ branches, they have re-skilled the women to be drivers (lorry and taxi) which is an area where there is a shortage of labour.

In January 2007 the employment service centres have been joined with the municipality centre for the unemployed and renamed job centres. These job centres are going to make employment plans and their effort will be evaluated by out-come audits. Gender is a category in the audits, but is not singled out in the employment plan guidance neither is the former effort to break down the gender segregated labour market. Furthermore, a cut down in local consultants specialising in gender has been carried through as a part of the structural reform, they have been replaced by a national gender equality centre.

The structural reform has also meant a reduction in influence of the labour market parties as the local employment councils have changed status from policy deciding to policy advising agencies. Strong corporatist structures and the tradition of negotiation between the parties both at national, regional, local and at workplace level are part of the 'deal' on flexicurity and necessary for both adapting labour and work-places to changes at the labour market and secure workers rights and pay. A weakening in the influences of the labour market parties could challenge the efficiency of the flexicurity model.

\section{DISCUSSION}

From flexicurity to flexicarity: In itself, flexicurity is gender-blind even though the focus on security for weaker groups is to the benefit of women in general $[18,17]$. However, the Danish flexicurity model suffers from the same problem as similar models (e.g. EspingAndersen's welfare regimes), namely it only focuses on the state-market relations and on social security, and not on the state-family relations or on services $[16,28]$. A strong support for women's labour market participation in Denmark has been provided by public care facilities for the children and elderly. Public care facilities support the flexibility of the labour market in different ways for example by delivering more labour to hire and fire and making it possible for both men and women to take part in qualifying activities. Leaving out public care facilities neglects gendered improvements in the Danish welfare society and the model becomes an inadequate description of the processes and relations which characterise the Danish flexicurity model. So the flexicurity model lacks a perspective - public care facilities. Denmark is, together with Sweden, known as one of the countries with the highest level of day-care for children enabling both parents to be on the labour market [1]. This is also acknowledged by Madsen, however, he only relates it to the background of the model. On the contrary I will suggest a change both in shape - from triangle to square - and in name - from flexicurity to flexicArity.

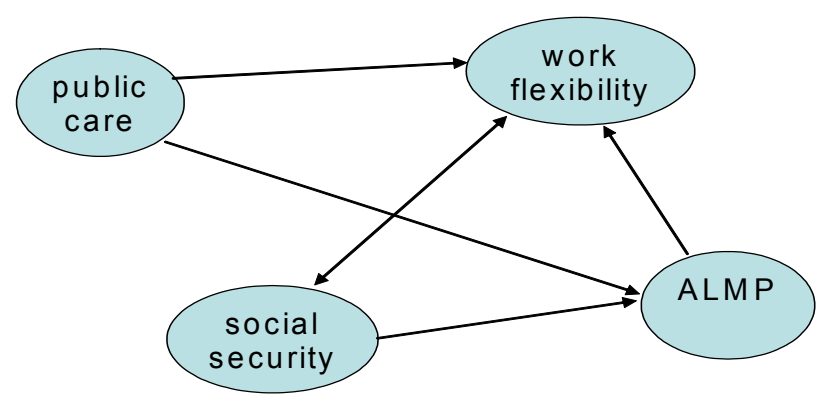

Fig. 1: The Danish flexicarity model

The importance of the principle of individualism: However, adding a fourth corner to the model does not fully solve the problem of gender sensitive modelbuilding, another important lesson to learn is the 
importance of the principle of individualism in social security and taxation. The principle has supported the economic independence of women and the defamilisation of welfare policies. According to Maria Jepsen 2005, non-individualised rights will hinder women's labour market participation and are not consistent with equal opportunities. However, recently, the principle of individualism has been weakened in favour of criteria building on the total income of the family [5]. This has in particular affected ethnic minorities on state social benefits. Breaking with the principle of individualism could lead both to a rise in gender inequality and become a barrier for women's labour market participation.

Points of which we should be aware: Although women have the same rights and obligations as men, they do not to the same extent gain from the active labour market policy. However, more thorough research into how the active labour market policy works in relation to gender is needed, this includes taking into consideration differences among women. I have not distinguished between different groups of women, but clearly belonging to the group of unskilled ethnic minority women on state benefits increases the problems, they are in risk of marginalisation as they are more likely to be able to meet neither the productivity demands nor have the required qualifications. On top of that, they risk reductions in social benefits.

Another point of which we should be aware is how the local employment policy will develop in the future. The structural reform has just been put into force (January $1^{\text {st }} 2007$ ), and the question arises of how the changes in the organisation of the gender effort will influence women and men's possibilities on the labour market. In the 1990's parental leave schemes were introduced during a period of high unemployment. The leave schemes were seen mainly as a labour market policy instrument, which could also help out busy families. However, this lack of a gender perspective on labour market policies resulted in the so-called leave-trap i.e. that women being on parental leave for a longer period of time had severe difficulties in returning to employment [11]. Furthermore, in 1999 the labour market parties made the Equal Treatment Agreement in which they declared their intention to work actively for promoting equal treatment in working life, therefore we must ask how the decrease of influence from the labour market parties and the increase of influence from the local government will influence gender equality. Finally, it is important to be aware of how also work time flexibility and functional flexibility influence the effectiveness of the flexicurity model and if and how flexibility in the labour market affects men and women differently [17].

Flexicarity and gender in/ equality in the Danish model: The Danish flexicurity model has a lot of advantages when meeting the present challenges to the labour market. However, the effectiveness and impact of the Danish flexicurity model cannot be 'judged' or 'measured' without taking into consideration a gender perspective both in model-building and in policystrategies. Adding a gender perspective has resulted in a mixed picture. On the one hand, the Danish flexicurity model has supported gender equality, but only if public care facilities and the principle of individualism are included in model-building. On the other hand, apparently the active labour market strategy does not improve women's employability to the same extent as men. I therefore suggest: adding public care-facilities as the fourth corner and change the name to the Danish flexicarity model; emphasizing the importance of the principle of individualism in social security and taxation; and further research with a gender perspective on both flexibility at the labour market and the active labour market policy

\section{ACKNOWLEDGMENTS}

The article is based on a lecture given in October 2006 at Ruskin College, Oxford. I would like to thank both Ruskin College for inviting me to be a research fellow and the head of the MA-programme: International Labour and Trade Union Studies, Sue Ledwith and the students for interesting discussions.

\section{REFERENCES}

1. Abrahamson, P., T.P. Boje and B. Greve, 2005. Welfare and Families in Europe. Ashgate

2. Anttonen, A., 2002. Universalism and social policy: a Nordic-feminist revaluation. In NORA 10 (2): $71-80$

3. Beskæftigelsesministeriet, 2006. Fakta om kvinder og mænd på arbejdsmarkedet, www.bm.dk eller www.ligeloen.dk

4. Borchorst, A. and B. Siim, 2002. The womenfriendly welfare states revisited. In NORA 10 (2): 90-98

5. Borchorst, A. and Siim, B., 2006. Køn, velfærdsbegrebet og kampen om definitionsmagten. www.kritiskdebat.dk

6. Christensen, A-D, and B. Siim, 2001. Køn, demokrati og modernitet. Mod nye politiske identiteter. Hans Reitzels Forlag 
7. Center for ligestillingsforskning (CELI), 2003. Ligeløn og lønforhandling. En rapport om ny løn i tre danske kommuner

8. Dedding, M. and K. Wong, 2004. Mænds og kvinders løn. En analyse af løngabet 1997-2001. Socialforskningsinstituttet 04:10

9. Due, J., J.S.Madsen and L. K. Pedersen, 1994. The Survival of the Danish Model, DJØF Publishing

10. Due, J. and J.S.Madsen, 2006. Fra storkonflikt til barselsfond. Den danske model under afvikling eller fornyelse, DJØF Forlag

11. Ellingsæter, A. L., 2000. Welfare states, labour markets and gender relations in transition - The decline of the Scandinavian model? In: Gender, Welfare State and the Market. Towards a new division of labour (eds Boje and Leira), pp: 89-110. Routledge

12. Esping-Andersen, G., 1990. The three worlds of welfare capitalism. Polity Press

13. Geerdsen, P.P. and L.P. Geerdsen, 2006. Fra aktivering til beskæftigelse. Socialforskningsinstituttet 06:20

14. Greve, B., forthcoming. What characterise the Nordic welfare state model. In Journal of Social Sciences

15. Hansen, H., Juul, M.M., Jakobsen, F., 2005. Uddannelse og tilskudsjob - prioritering på et fejlagtigt grundlag? Tidsskrift for Arbejdsliv 7(2): 27-37

16. Hansen, L. L., 2002. Rethinking the industrial relations tradition from a gender perspective: an invitation to integration. Employee Relations Journal 24 (2):190-210

17. Healy, G., forthcoming. Flexicurity - the UK picture. In: How secure is flexicurity? (eds. M. Jepsen and M. Keune, Peter Lang

18. Jepsen, M., 2005. Towards a Gender Impact Analysis of Flexicurity. In: Employment policy from different angles (eds. Bredgaard \& Larsen) pp.339-350, DJØF Publishing

19. Kristensen, C..J., forthcoming. Ethnic diversity and the principle of universalism. In Journal of Social Science
20. LO \& DA, 2003. Kvinder og mænds løn. LO \& DA

21. LO, 2006. Ligestillingsregnskab 2005. www.loli.dk

22. Madsen, P.K., 2004. The Danish model of 'flexicurity': experiences and lessons. TRANSFER. European Review of Labour and Research 10 (2): 187-207

23. Madsen, P. K., 2005. The Danish Road to 'Flexicurity'. Where are we? And how did we get there. In: Employment policy from different angles (eds Bredgaard \& Larsen) pp. 269-290. DJØF Publishing

24. Madsen, P. K., 2006a. How can it possibly fly? The paradox of a dynamic labour market in a Scandinavian welfare state. In: National Identity and a Variety of Capitalism: The Case of Denmark (eds Campell et al), McGill University Press

25. Madsen, P. K., 2006b. The Danish Model of 'Flexicurity. Powerpoint presentation, European Foundation for Living and Working Conditions, May 23, 2006

26. Minister for Ligestilling, 2006. Fakta om ligestilling 2006

27. Scheuer, S., 2007. Dilemmas of Collectivism Danish Trade Unions in the $21^{\text {st }}$ Century. In Journal of Labor Research vol. 28 (2): 233-254

28. Siim, B., 2005. Chapter ten: Gender equality, citizenship and welfare state restructuring. In: The Changing Face of Welfare. Consequences and outcomes from a citizenship perspective (eds Campell et al) pp. 169-187. Polity Press

29. Statistik om kvinder og mænd, 2007. Minister for Ligestilling. Data fra 2005

30. Statistisk Årbog 2006. Danmarks Statistik

31. Videnscenter for Ligestilling, 2001. 'Også er der lige lønnen...'

32. Wilthagen, T. and F.Tros, 2004. The concept of 'flexicurity': a new approach to regulating employment and labour markets. In Transfer 10 (2): $166-185$ 